\title{
BODY CHOLESTEROL METABOLISM IN MAN. I. THE EQUILIBRATION OF SERUM AND TISSUE CHOLESTEROL * $†$
}

\author{
By ARAM V. CHOBANIAN $\ddagger$ AND WILLIAM HOLLANDER § WITH THE TECH NICAL \\ ASSISTANCE OF MARGARET SULLIVAN AND MARILYN COLOMBO \\ (From the Robert Dawson Evans Memorial, Department of Clinical Research, Massachusetts \\ Memorial Hospitals, and the Department of Medicine, Boston University \\ School of Medicine, Boston, Mass.)
}

(Submitted for publication March 1, 1962; accepted May 17, 1962)

This study was undertaken to investigate the differential rates of exchange and the extent of the equilibration between serum and tissue cholesterol in man over prolonged periods of time. Previous studies in animals have pointed to species differences in the exchange of cholesterol between the serum and tissue compartments. Gould has reported that tissue cholesterol in dogs appears to be in a dynamic state of equilibrium with serum cholesterol and that equilibration of serum and tissue cholesterol can be demonstrated within 14 days after the administration of $\mathrm{C}^{14}$ cholesterol (2). Studies in rats by Avigan and Steinberg, however, have suggested that complete equilibration between serum and tissue cholesterol is not present even after periods ranging up to 7 weeks (3).

The present studies in man indicate that the cholesterol in all body tissues other than nervous tissue constitutes a "pool" which appears to exchange with the serum cholesterol. The studies also have demonstrated that complete equilibration of serum and arterial intimal cholesterol does occur in normal human blood vessels, although at rates that are generally slower than those observed in other body tissues.

* A preliminary report of this work was presented at the Annual Meeting of the American Federation for Clinical Research, May 1, 1960, and appeared in abstract form (1). The work was supported in part by Grant PHS-H-1536 (C8) from the National Heart Institute and in part by a grant from Mr. U. A. Whitaker.

† Submitted in honor of Chester S. Keefer, M.D., and the Golden Anniversary of the Evans Memorial Department of Clinical Research, Boston, Mass.

$\ddagger$ A portion of this work was done on a Postdoctoral Fellowship of the National Heart Institute.

§ Special Research Fellow, National Institutes of Health.

\section{MATERIAL AND METHODS}

Seven hospitalized patients terminally ill with neoplastic disease, one hospitalized patient with an acute cerebral thrombosis, and one ambulatory patient who died suddenly from a pulmonary embolism were included in the study. None of the patients had evidence of hypercholesterolemia, diabetes mellitus, thyroid dysfunction, or the nephrotic syndrome. Five of the patients with malignancies showed signs of tissue wasting, but the remaining individuals appeared to be in a good nutritional state.

All patients were given a tracer dose of $4-\mathrm{C}^{14}$-cholesterol at intervals ranging from 1 to 226 days prior to death. The labeled cholesterol used for injection was obtained commercially (New England Nuclear Corp.) and had a specific activity of $37.7 \mu \mathrm{c}$ per $\mathrm{mg}$ cholesterol. It was dissolved in ethanol and passed through a sintered glass filter. The ethanol solution was diluted with saline and mixed with approximately $30 \mathrm{ml}$ of the patient's own plasma which had been obtained on the day of cholesterol administration. This mixture, representing 20 to $30 \mu \mathrm{c}$ of $\mathrm{C}^{14}$-cholesterol, was injected into an antecubital vein through an indwelling needle.

Specimens of liver, kidney, spleen, lung, adrenal gland, intestine, fat, muscle, vena cava, pulmonary artery, coronary artery, femoral artery, aorta, and brain were removed at autopsy 4 to 10 hours after the patient's death and immediately frozen. Blood specimens were obtained either antemortem on the day of the patient's death or during the post-mortem examination. Because of postmortem hemolysis, specific activities of whole blood cholesterol, rather than separate serum and red cell specific activities, were determined in those blood samples obtained at autopsy. All adventitial material was stripped away from the tissues to be analyzed. The tissues were minced, ground, and extracted into boiling acetone and alcohol. Aliquots of the extract were used for the determination of free and total cholesterol content by the method of Schoenheimer and Sperry (4). Duplicate aliquots were also analyzed for free and total $\mathrm{C}^{\mathbf{1 4}}$-cholesterol radioactivity. To measure $\mathrm{C}^{\mathbf{1 4}}$ radioactivity in the free cholesterol fraction, the acetone-alcohol extract was acidified, and the cholesterol was precipitated with digitonin. The samples were washed once with acetone and ether and twice with ether and were then dried. The digitonide precipitate was dissolved in $2 \mathrm{ml}$ methanol 
TABLE I

The equilibration of serum and tissue cholesterol in nine human subjects

\begin{tabular}{|c|c|c|c|c|c|c|c|c|c|c|c|c|c|c|c|}
\hline \multirow{3}{*}{$\begin{array}{l}\text { Patient } \\
\text { Sex } \\
\text { Age }\end{array}$} & \multirow[b]{3}{*}{ Wt } & \multirow[b]{3}{*}{ Diagnosis } & \multirow[b]{3}{*}{ Timet } & \multicolumn{12}{|c|}{ Tissue cholesterol-4-C14 specific activity $*$} \\
\hline & & & & \multicolumn{2}{|c|}{ Serum } & \multicolumn{2}{|c|}{$\mathrm{RBC}$} & \multicolumn{2}{|c|}{ Liver } & \multicolumn{2}{|c|}{ Spleen } & \multicolumn{2}{|c|}{ Kidney } & \multicolumn{2}{|c|}{ Lung } \\
\hline & & & & Free & Total & Free & Total & Free & Total & Free & Total & Free & Total & Free & Total \\
\hline & $k g$ & & days & & & & & & & & & & & & \\
\hline H.C. $९ 56$ & 62.0 & $\begin{array}{c}\text { Carcinoma } \\
\text { of breast }\end{array}$ & 1 & $320_{+}^{+}$ & & 247 & & 648 & & 132 & & 68 & & 99 & \\
\hline R.D. $\sigma^{7} 43$ & 64.7 & Monocytic & 4 & $560+$ & & & & 620 & & 584 & & 382 & & 326 & \\
\hline A.W. $\sigma^{\pi} 75$ & 60.9 & $\begin{array}{l}\text { Carcinoma } \\
\text { of lung }\end{array}$ & 6 & 501 & & 544 & & 561 & & 346 & & 201 & & 256 & \\
\hline R.N. $\sigma^{x} 69$ & 83.5 & $\begin{array}{l}\text { Cerebral } \\
\text { thrombosis }\end{array}$ & 15 & $376 \pm$ & 370 & & & 359 & 364 & 375 & 400 & 392 & 358 & 409 & 432 \\
\hline E.M. $\$ 77$ & 53.6 & $\begin{array}{l}\text { Carcinoma } \\
\text { of stomach }\end{array}$ & 17 & 226 & 214 & 239 & 230 & 208 & 230 & 224 & 230 & 206 & 228 & 244 & 229 \\
\hline M.L. $\quad 442$ & 59.8 & $\begin{array}{l}\text { Pulmonary } \\
\text { embolism }\end{array}$ & 20 & 308 & 329 & 313 & 332 & 307 & 294 & 313 & 321 & 334 & 350 & 338 & 362 \\
\hline R.L. $\quad 77$ & 71.3 & $\begin{array}{l}\text { Cerebral } \\
\text { thrombosis }\end{array}$ & 30 & $129 \ddagger$ & 138 & & & 127 & 125 & 137 & 133 & 123 & 140 & 146 & 135 \\
\hline A.M. $\sigma^{7} 19$ & 68.6 & $\begin{array}{l}\text { Monocytic } \\
\text { leukemia }\end{array}$ & 125 & 38 & 42 & 36 & 37 & 38 & 41 & 41 & 41 & 42 & 39 & 34 & 38 \\
\hline J.G. $\quad \& 48$ & 44.5 & $\begin{array}{c}\text { Carcinoma } \\
\text { of breast }\end{array}$ & 226 & $21 \ddagger$ & 22 & & & 20 & 21 & 24 & 21 & 21 & 19 & 18 & 21 \\
\hline
\end{tabular}

\begin{tabular}{|c|c|c|c|c|c|c|c|c|c|c|c|c|c|c|c|}
\hline \multirow{3}{*}{$\begin{array}{c}\text { Patient } \\
\text { Sex } \\
\text { Age }\end{array}$} & \multirow[b]{3}{*}{ Wt } & \multirow[b]{3}{*}{ Diagnosis } & \multirow[b]{3}{*}{ Timet } & \multicolumn{12}{|c|}{ Tissue cholesterol-4-C ${ }^{14}$ specific activity * } \\
\hline & & & & \multicolumn{2}{|c|}{ Adrenal } & \multicolumn{2}{|c|}{ Intestine } & \multicolumn{2}{|c|}{ Muscle } & \multicolumn{2}{|c|}{ Fat } & \multicolumn{2}{|c|}{$\begin{array}{l}\text { Abdominal } \\
\text { aorta }\end{array}$} & \multicolumn{2}{|c|}{ Brain } \\
\hline & & & & Free & Total & Free & Total & Free & Total & Free & Total & Free & Total & Free & Total \\
\hline & kg & & days & & & & & & & & & & & & \\
\hline H.C. $\subsetneq 56$ & 62.0 & $\begin{array}{c}\text { Carcinoma } \\
\text { of breast }\end{array}$ & 1 & 33 & & 19 & & 13 & & 10 & & 3 & & $\mathbf{0}$ & \\
\hline R.D. ơ 43 & 64.7 & $\begin{array}{c}\text { Monocytic } \\
\text { leukemia }\end{array}$ & 4 & 204 & & 110 & & 54 & & 56 & & 39 & & 0 & \\
\hline A.W. ه্ 75 & 60.9 & $\begin{array}{l}\text { Carcinoma } \\
\text { of lung }\end{array}$ & 6 & 153 & & 71 & & 79 & & 56 & & 35 & & $\mathbf{0}$ & \\
\hline R.N. व7 69 & 83.5 & $\begin{array}{l}\text { Cerebral } \\
\text { thrombosis }\end{array}$ & 15 & 322 & 344 & 314 & 301 & 282 & 253 & 76 & 62 & 53 & 32 & 7 & 5 \\
\hline E.M. $\quad 77$ & 53.6 & $\begin{array}{l}\text { Carcinoma } \\
\text { of stomach }\end{array}$ & 17 & 180 & 187 & 201 & 206 & 134 & 148 & 109 & 120 & 20 & 23 & 3 & 3 \\
\hline M.L. \& 42 & 59.8 & $\begin{array}{l}\text { Pulmonary } \\
\text { embolism }\end{array}$ & 20 & 308 & 284 & 260 & 282 & 337 & 320 & 226 & 216 & 138 & 130 & 8 & 10 \\
\hline R.L. $\quad 74$ & 71.3 & $\begin{array}{l}\text { Cerebral } \\
\text { thrombosis }\end{array}$ & 30 & 111 & 120 & 115 & 113 & 122 & 130 & 101 & 117 & 32 & 30 & 5 & 3 \\
\hline A.M. ơ 19 & 68.6 & $\begin{array}{l}\text { Monocytic } \\
\text { leukemia }\end{array}$ & 125 & 43 & 41 & 37 & 39 & 44 & 46 & 40 & 43 & 36 & 38 & 2 & 1 \\
\hline J.G. $\quad \& 48$ & 44.5 & $\begin{array}{c}\text { Carcinoma } \\
\text { of breast }\end{array}$ & 226 & & & 23 & 20 & 19 & 20 & 23 & 23 & 24 & 26 & 1 & 1 \\
\hline
\end{tabular}

* Cholesterol-4-C14 specific activity $=\mathrm{cpm} \mathrm{C}^{14}$-cholesterol (digitonide precipitable material) $/ \mathrm{mg}$ cholesterol.

+ Time $=$ interval between $C^{14}-$ cholesterol administration and death of patients.
Whole blood cholesterol-4-C14 specific activity.

and counted in a Tri-Carb liquid scintillation spectrometer after the addition of $18 \mathrm{ml}$ of scintillation solution. ${ }^{1}$ For determinations of total cholesterol radioactivity, duplicate aliquots of the acetone-alcohol extract were saponified with $\mathrm{KOH}$, acidified, and then handled in the manner described for measurement of free cholesterol radioactivity. All radioactive samples were counted to a statistical accuracy of at least 5 per cent (5). Variations in counting between duplicate samples were not greater than 4 per cent.

In the blood vessels that were analyzed, the intima and adventitia were stripped from each other without an attempt to separate the media. Whenever possible, atherosclerotic segments of the arteries were separated from relatively normal areas and analyses of the sepa-

1 Prepared as follows: $4.0 \mathrm{~g}$ of 2,5-diphenyloxazole (PPO) and $0.1 \mathrm{~g}$ of 1,4-di-2-(5-phenyloxazolyl)-benzene (POPOP) were made up to $1 \mathrm{~L}$ with toluene. rated portions for cholesterol specific activity were made. The degree of atherosclerosis was estimated grossly on a scale of 0 to $4+$, where 0 represented absence of visible atherosclerosis; $1+$ minimal but visible fatty streaking; $2+$ few plaques but little or no vessel narrowing; $3+$ numerous but discrete plaques with some vessel narrowing but generally no ulceration or calcification; and $4+$ severe atherosclerosis with numerous plaques, frequently confluent, calcified, ulcerating, and causing vessel narrowing. Segments of arterial tissue were dried to a constant weight, and the cholesterol content and cholesterol specific activity were determined as described above.

In Patient M.L. the cholesterol in aliquots of the acetone-alcohol extracts of serum, liver, kidney, spleen, and muscle were purified by the bromination method of Schwenk and Werthessen (6), and the cholesterol specific activity of the purified material was determined as previously described.

In Patients A.M. and J.G. a lipid extract of serum, 
TABLE II

The equilibration of serum and blood vessel cholesterol in nine human patients

\begin{tabular}{|c|c|c|c|c|c|c|c|c|c|c|}
\hline \multirow[b]{2}{*}{ Patient } & \multirow[b]{2}{*}{ Time } & \multirow[b]{2}{*}{$\begin{array}{l}\text { Serum } \\
\text { Sp. act.* }\end{array}$} & \multirow[b]{2}{*}{$\begin{array}{c}\text { Vena } \\
\text { cava } \\
\text { Sp. act. }\end{array}$} & \multirow[b]{2}{*}{$\begin{array}{c}\text { Pulmonary } \\
\text { artery } \\
\text { Sp. act. }\end{array}$} & \multicolumn{2}{|c|}{$\begin{array}{l}\text { Coronary } \\
\text { artery }\end{array}$} & \multicolumn{2}{|c|}{$\begin{array}{l}\text { Abdominal } \\
\text { aorta }\end{array}$} & \multicolumn{2}{|c|}{$\begin{array}{c}\text { Femoral } \\
\text { artery }\end{array}$} \\
\hline & & & & & $\begin{array}{c}\text { Degree of } \\
\text { atheroscl. } \\
0-4+\end{array}$ & $\begin{array}{l}\text { Sp. } \\
\text { act. }\end{array}$ & $\begin{array}{l}\text { Degree of } \\
\text { atheroscl. } \\
0-4+\end{array}$ & $\begin{array}{l}\text { Sp. } \\
\text { act. }\end{array}$ & $\begin{array}{l}\text { Degree of } \\
\text { atheroscl. } \\
0-4+\end{array}$ & $\begin{array}{l}\text { Sp. } \\
\text { act. }\end{array}$ \\
\hline & days & & & & & & & & & \\
\hline $\begin{array}{l}\text { H.C. } \\
\text { R.D. } \\
\text { A.W. } \\
\text { R.N. } \\
\text { E.M. } \\
\text { M.L. } \\
\text { R.L. } \\
\text { A.M. } \\
\text { J.G. }\end{array}$ & $\begin{array}{r}1 \\
4 \\
6 \\
15 \\
17 \\
20 \\
30 \\
125 \\
226\end{array}$ & $\begin{array}{r}320 \\
560 \\
501 \\
376 \\
226 \\
308 \\
129 \\
38 \\
21\end{array}$ & $\begin{array}{r}32 \\
109 \\
108 \\
176 \\
193 \\
341 \\
106 \\
44 \\
19\end{array}$ & $\begin{array}{r}30 \\
93 \\
73 \\
81 \\
79 \\
231 \\
80 \\
45 \\
20\end{array}$ & $\begin{array}{l}4+ \\
1+ \\
4+ \\
3+ \\
4+ \\
2+ \\
3+ \\
0+ \\
1+\end{array}$ & $\begin{array}{r}3 \\
56 \\
26 \\
56 \\
23 \\
148 \\
33 \\
37 \\
23\end{array}$ & $\begin{array}{l}4+ \\
1+ \\
3+ \\
4+ \\
4+ \\
1+ \\
2+ \\
0+ \\
1+\end{array}$ & $\begin{array}{r}3 \\
39 \\
35 \\
53 \\
20 \\
138 \\
32 \\
36 \\
24\end{array}$ & $\begin{array}{l}4+ \\
2+ \\
3+ \\
3+ \\
3+ \\
1+ \\
2+ \\
0 \\
0\end{array}$ & $\begin{array}{r}4 \\
59 \\
34 \\
76 \\
30 \\
137 \\
36 \\
36 \\
22\end{array}$ \\
\hline
\end{tabular}

*Sp. act. $=$ cpm C14-free cholesterol/mg free cholesterol.

liver, spleen, intestine, kidney, and fat was made according to the method of Folch, Lees and Stanley (7) and the total $\mathrm{C}^{14}$ radioactivity of duplicate aliquots of the lipid extract was measured after addition of the previously described scintillation solution. Duplicate aliquots of the same lipid extract were also treated with digitonin and analyzed for $\mathrm{C}^{14}$-cholesterol radioactivity as described above.

Equilibration of cholesterol between the serum and tissues

1. Liver and red blood cells. The cholesterol in the liver and red cells showed the most rapid rate of equilibration with serum cholesterol as compared with the other tissues studied (Table I). Essentially complete equilibration was noted between these tissues in all patients studied except the one who died 14 hours after receiving $\mathrm{C}^{14}$-cholesterol; this patient had specific activities of liver and red cell cholesterol that were 202 and 77 per cent, respectively, of the serum specific activity. During the 4 to 226 days after $\mathrm{C}^{14}$-cholesterol administration, free and total cholesterol specific activities in the liver ranged from 92 to 112 per cent of the serum specific activity, whereas the red cell specific activities ranged from 88 to 108 per cent of the serum specific activity. The specific activities of free and total cholesterol in these tissues were generally comparable to each other.

2. Kidney, spleen, lung, adrenal, and intestine. Isotopic equilibrium between the serum cholesterol and the cholesterol in the kidney, spleen, lung, adrenal gland, and intestine was generally reached within 20 days after the administration of labeled cholesterol. The relative tissue specific activities from day 30 onward ranged from 86 to 110 per cent of the serum specific activity for the kidney, 95 to 114 per cent for spleen, 86 to 113 per cent for lung, 86 to 113 per cent for adrenal, and 83 to 110 per cent for intestine. No consistent differences between the specific activities of free and total cholesterol were observed.

3. Fat and muscle. Almost complete equilibration of fat and muscle cholesterol with serum cholesterol was reached in 30 days, and the equilibrium state appeared to persist at 125 and 226 days. The specific activity of the cholesterol in fat tissue ranged from 78 to 110 per cent of the serum specific activity, whereas that in the muscle ranged from 90 to 116 per cent of the serum specific activity between days 30 and 226 .

4. Blood vessels. Inferior vena cava-Of the blood vessels examined (Table II), the exchange of tissue cholesterol with serum cholesterol was most rapid in the vena cava, where essentially complete equilibration with the serum cholesterol occurred at 20 to 30 days and persisted during the remainder of the study.

Pulmonary artery-The rate of equilibration of serum cholesterol with that in the pulmonary artery was intermediate between those observed in the vena cava and systemic arteries. During the first month the maximum cholesterol specific activity in the pulmonary artery was 75 per cent of the serum specific activity. At 125 and 226 days, equilibration was essentially complete, and cholesterol specific activities in the pulmonary artery were

TABLE III

Comparison of the degree of atherosclerosis, intimal cholesterol content, and the equilibration between serum and aortic intimal cholesterol

\begin{tabular}{|c|c|c|c|c|}
\hline Patient & Time & $\begin{array}{c}\text { Degree } \\
\text { atheroscl. } \\
0-4+\end{array}$ & $\begin{array}{c}\text { Aortic } \\
\text { intimachol }\end{array}$ & $\begin{array}{c}\text { Degree } \\
\text { equi- } \\
\text { libra- } \\
\text { tion* }\end{array}$ \\
\hline & days & & $\underset{\text { dry wt }}{m g}$ & $\%$ \\
\hline $\begin{array}{l}\text { H.C. } \\
\text { R.D. }\end{array}$ & $\begin{array}{l}1 \\
4\end{array}$ & $\begin{array}{l}4+ \\
1+ \\
3+\end{array}$ & $\begin{array}{l}86.4 \\
26.8 \\
44.3\end{array}$ & $\begin{array}{l}1 \\
7 \\
2\end{array}$ \\
\hline $\begin{array}{l}\text { A.W. } \\
\text { R.N. } \\
\text { E.M. }\end{array}$ & $\begin{array}{r}6 \\
15 \\
17\end{array}$ & $\begin{array}{l}3+ \\
4+ \\
2+ \\
4+\end{array}$ & $\begin{array}{r}38.2 \\
104.1 \\
27.4 \\
59.7\end{array}$ & $\begin{array}{r}7 \\
14 \\
13 \\
9\end{array}$ \\
\hline M.L. & 20 & $\begin{array}{l}1+ \\
3+\end{array}$ & $\begin{array}{r}7.9 \\
36.4\end{array}$ & $\begin{array}{l}45 \\
24\end{array}$ \\
\hline R.L. & 30 & $2+$ & $\begin{array}{l}48.5 \\
51.5\end{array}$ & 25 \\
\hline $\begin{array}{l}\text { A.M. } \\
\text { J.G. }\end{array}$ & $\begin{array}{l}125 \\
226\end{array}$ & $\begin{array}{l}0 \\
\mathbf{1} \\
1+\end{array}$ & $\begin{array}{r}7.1 \\
13.4 \\
19.5\end{array}$ & $\begin{array}{r}95 \\
108 \\
114\end{array}$ \\
\hline
\end{tabular}

* Degree equilibration of serum and aortic intimal cholesterol $(\%)=$ (C14-cholesterol sp. act. of aortic intima/C14-cholesterol sp. act. of serum) $\times 100$. 
118 and 95 per cent of the serum cholesterol specific activities.

Systemic arteries-As compared with the other tissues, the rate of equilibration of serum cholesterol with that in the arterial intima appeared to be a relatively slow process. At the end of 30 days the maximum arterial intimal specific activity was 45 per cent of the serum specific activity. By 125 and 226 days after $\mathrm{C}^{14}$-cholesterol administration, the arterial intimal specific activities in two patients without vascular disease ranged between 93 and $\mathbf{1 1 8}$ per cent of the serum specific activities.

Analyses of different areas of intima in the same patient, and comparison of intimal cholesterol specific activities in different patients who died at generally similar intervals after labeled cholesterol administration (Table III), indicate that the rate of exchange of serum and intimal cholesterol is inversely related to the degree of atherosclerosis and the cholesterol content of the vessels examined. In Patient M.L. a relatively normal segment of aorta with a cholesterol content of $7.9 \mathrm{mg}$ per $\mathrm{g}$ dry tissue had a $\mathrm{C}^{14}$-cholesterol specific activity of 45 per cent as compared with a neighboring atherosclerotic segment where there was a cholesterol concentration of $36.4 \mathrm{mg}$ per $\mathbf{g}$ and a cholesterol specific activity which was 24 per cent of that in the serum. Likewise, in Patient R.L. an aortic segment with grade 2 atherosclerosis had a specific activity which was 25 per cent of that in the serum in contrast to the cholesterol specific activity of 17 per cent in an adjacent severely atherosclerotic area. In Patients R.N., E.M., and M.L., who died at roughly comparable intervals of 15,17 , and 20 days, respectively, after receiving labeled cholesterol, different relative aortic intimal specific activities were present. Patients R.N. and E.M., with severe atherosclerosis, had aortic specific activities of only 14 and 9 per cent of their serum specific activities, whereas Patient M.L., with a relatively normal aorta, had an aortic intimal specific activity which was 45 per cent of that in the serum.

In the patients studied, the cholesterol specific activities of the abdominal aorta, coronary artery, and femoral artery were generally comparable to one another when the degree of atherosclerosis of the segments examined was taken into account.

5. Central nervous system. The brain specific activity in all pataients studied was low and ranged from 0 to 5 per cent of the serum specific activity levels.

Noncholesterol $\mathrm{C}^{\mathbf{1 4}}$ tissue radioactivity-The specific activities of the digitonin-precipitable material of the tissues were comparable before and after dibromide purification. No measureable $\mathrm{C}^{14}$ radioactivity other than that in the digitonin-precipitable material was found in the lipid-soluble extract of the tissues.

\section{DISCUSSION}

The rate of exchange of serum and tissue cholesterol appears to vary among the different tissues of the body. Similarly to previous reports (8-11), the present investigation indicates that the liver and red blood cell cholesterol exchanges rapidly with serum cholesterol and that in these tissues complete equilibration is reached within 4 days. In most of the other tissues studied the equilibration with serum cholesterol is more or less complete within 1 month. Over longer periods (ranging up to 7 months), a state of equilibrium appears to persist, tissue cholesterol specific activities remaining generally similar to the serum specific activities.

The rate at which serum cholesterol exchanges with cholesterol in the arteries is slower than in the other tissue studied except the brain. However, as has been reported previously $(8,12,13)$, significant exchange may take place in the arteries. The present studies indicate that in normal arterial intima complete equilibration with serum cholesterol does occur. Significant amounts of cholesterol radioactivity were demonstrated in atherosclerotic plaques, although within the time period of these studies, complete exchange was not observed. The observation that cholesterol specific activity in atherosclerotic segments was lower than in less diseased areas suggests that the presence of atherosclerosis delays the rate at which complete equilibration between serum and intimal cholesterol takes place. The lower specific cholesterol activities in the plaques does not necessarily mean that less total cholesterol is exchanging in the plaques, since most of the atherosclerotic segments analyzed had significantly higher cholesterol concentrations than had less diseased areas. The demonstration of complete equilibration of cholesterol between the serum and normal intima indicates that the cholesterol of normal arterial intima is in a dynamic state of equilibrium with serum cholesterol. These observations lend some rationale to the use of hypocholesterolemic measures in the prevention of atherosclerosis.

The equilibration of serum and intimal cholesterol suggests that at least some of the cholesterol deposited in the vessel wall had its origin in the serum cholesterol. Recent studies in rabbits have indicated that the entrance of cholesterol into the intima from the serum accounts for practically all of the cholesterol being deposited in the vessel wall, thus suggesting that in situ arterial cholesterol synthesis does not play a significant role in the accumulation of cholesterol in arteries (14). The present study does not yield informa- 
tion regarding the relative importance of these factors in man, but it has been demonstrated in vitro that in situ sterol synthesis does occur in human arterial tissue $(15,16)$.

The similar specific activities of cholesterol in the coronary artery, thoracic and abdominal aorta, and femoral artery of each patient indicates that similar rates of exchange with serum cholesterol were present in these areas. These results are unlike those reported recently with in vitro preparations in which differential rates of penetration of labeled cholesterol into different segments of the aorta were observed (17).

The brain and other nervous tissue were the only tissues that showed negligible degrees of exchange with the serum cholesterol. These findings, along with the observation that the brain synthesis of cholesterol appears almost to cease after completion of myelinization (18), suggest that the turnover of brain cholesterol in adults is an extremely slow process. They also indicate that most of the cholesterol in the central nervous system is outside the cholesterol miscible pool that can be measured by isotope dilution techniques (19).

Segments of skin were not analyzed in the present investigation, but collateral studies have indicated that the cholesterol in the skin is also a part of the cholesterol miscible pool (19).

The measurement of absolute rates of exchange of cholesterol between the blood and tissues could not be determined from these studies in which the tissues were analyzed at varying intervals after the administration of a single dose of labeled cholesterol. The rate at which the specific activities of the serum and tissue compartments approach each other depends not only on the rate of transfer of labeled cholesterol from the serum to the tissues but also on the rate of decay of labeled cholesterol in the serum compartment. Initially, the blood levels of $\mathrm{C}^{\mathbf{1 4}}$-cholesterol specific activity decrease rapidly by a series of decreasing exponential rates $(13,19,20)$ and, during the periods in which the blood cholesterol radioactivity is greatest, more labeled cholesterol enters the tissues than at later stages when lesser concentrations of labeled cholesterol are present in the blood. Nevertheless, these studies are useful in comparing relative rates of exchange of serum and tissue cholesterol and, when they are conducted over intervals long enough to allow complete equilibration to occur, they. do yield information needed to identify the tissue compartments comprising the miscible pool of cholesterol.

\section{SUMMARY AND CONCLUSIONS}

1. Post-mortem analyses of tissues for specific activity of $\mathrm{C}^{14}$-cholesterol have been performed in nine patients who died 1 to 226 days after receiving tracer doses of $\mathrm{C}^{\mathbf{1 4}}$-labeled cholesterol.

2. The rate of equilibration of serum and tissue cholesterol varied among the different body tissues.

3. With the exception of the cholesterol in the brain and blood vessels, all tissues studied attained complete equilibration with serum cholesterol within 1 month and maintained it throughout the remainder of the 7-month study.

4. The brain cholesterol showed negligible degrees of equilibration with serum cholesterol throughout the period of study.

5. Complete equilibration of arterial intimal cholesterol with serum cholesterol was demonstrated after prolonged periods of study.

6. Significant $\mathrm{C}^{14}$-cholesterol radioactivity was present in atherosclerotic plaques of the patients studied, but the presence of atherosclerosis appeared to retard the rate at which equilibration with serum cholesterol occurred.

7. The miscible body pool of cholesterol in man includes the cholesterol in all the body tissues outside the nervous system.

8. The cholesterol in normal human blood vessels is in a dynamic state of equilibrium with serum cholesterol.

\section{REFERENCES}

1. Chobanian, A. V., and Hollander, W. The equilibration of cholesterol between the blood and tissues in man. Clin. Res. 1960, 8, 179.

2. Gould, R. G. Factors controlling cholesterol synthesis in the body. Proc. Ann. Meeting American Heart Association, Council for High Blood Pressure Research 1952, p. 3.

3. Avigan, J., and Steinberg, D. On the interpretation of disappearance curves of radioactive serum cholesterol (abstract). Circulation 1959, 20, 966.

4. Schoenheimer, R., and Sperry, W. M. A micromethod for the determination of free and combined cholesterol. J. biol. Chem. 1934, 106, 745. 
5. Loevinger, R., and Berman, M. Efficiency criteria in radioactivity counting. Nucleonics 1951,9 , no. 1 , 26.

6. Schwenk, E., and Werthessen, N. T. Studies on the biosynthesis of cholesterol. III. Purification of $\mathrm{C}^{14}$-cholesterol from perfusions of livers and other organs. Arch. Biochem. 1952, 40, 334.

7. Folch, J., Lees, M., and Stanley, G. H. A simple method for the isolation and purification of total lipides from animal tissues. J. biol. Chem. 1957, 226, 497.

8. Biggs, M. W., Kritchevsky, D., Colman, D., Gofman, J. W., Jones, H. B., Lindgren, F. T., Hyde, G., and Lyon, T. P. Observations on the fate of ingested cholesterol in man. Circulation 1952, 6, 359.

9. Gould, R. G., LeRoy, G. V., Okita, G. T., Kabara, J. J., Keegan, P., and Bergenstal, D. M. Use of $\mathrm{C}^{14}$-labeled acetate to study cholesterol metabolism in man. J. clin. Lab. Med. 1955 46, 372.

10. Eckles, N. E., Taylor, C. B., Campbell, D. J., and Gould, R. G. The origin of plasma cholesterol and the rates of equilibration of liver, plasma, and erythrocyte cholesterol. J. Lab. clin. Med. 1955. 46, 359.

11. Porte, D., Jr., and Havel, R. J. The use of cholesterol-4- $\mathrm{C}^{14}$-labeled lipoproteins as a tracer for plasma cholesterol in the dog. J. Lip. Res. 1961, 2, 357.
12. Gould, R. G., Jones, R. J., and Wissler, R. W. Lability of cholesterol in human atherosclerotic plaques (abstract). Circulation 1959, 20, 967.

13. Kurland, G. S., Lucas, J. L., and Freedberg, A. S. The metabolism of intravenously infused $\mathrm{C}^{14}-1 \mathrm{a}$ beled cholesterol in euthyroidism and myxedema. J. Lab. clin. Med. 1961, 57, 574.

14. Newman, H. A. I., and Zilversmit, D. B. The origin of cholesterol and cholesterol ester of rabbit atheroma. Fed. Proc. 1961, 20, 92.

15. Azarnoff, D. L. Species differences in cholesterol biosynthesis by arterial tissue. Proc. Soc. exp. Biol. (N. Y.) 1958, 98, 680.

16. Chobanian, A. V., and Hollander, W. Observations on the synthesis of sterols in human blood vessels. Clin. Res. 1961, 9, 137.

17. Duncan, L. E., Jr., and Buck, K. Passage of labeled cholesterol into the aortic wall of the normal dog. Circulat. Res. 1959, 7, 765.

18. Srere, P. A., Chaikoff, I. L., Treitman, S. S., and Burstein, L. S. The extrahepatic synthesis of cholesterol. J. biol. Chem. 1950, 182, 629.

19. Chobanian, A. V., Burrows, B. A., and Hollander, W. Body cholesterol metabolism in man. II. Measurement of the body cholesterol miscible pool and turnover rate. J. clin. Invest. 1962, 41, 1738.

20. Hellman, L., Rosenfeld, R. W., and Gallagher, T. F. Cholesterol synthesis from $\mathrm{C}^{14}$ acetate in man. $\mathrm{J}$. clin. Invest. 1954, 33, 142. 